\title{
INTRODUCTION TO THE SYMPOSIUM ON THE PRESENT AND FUTURE OF FOREIGN OFFICIAL IMMUNITY
}

\author{
Curtis A. Bradley*
}

It is generally accepted that, under customary international law, government officials are entitled to certain immunities in civil suits and criminal prosecutions in the domestic courts of other nations, assuming such immunities have not been waived by their government. Some high-level officials such as heads of state are entitled, while they are in office, to status-based immunity, also known as immunity ratione personae. This immunity is essentially absolute and extends even to private conduct. ${ }^{1}$ A much broader class of government officials is entitled to conduct-based immunity, also known as immunity ratione materiae. This immunity can be invoked even after the official is out of office, but it extends only to acts that they took in an official capacity while in office. At least since the Pinochet litigation in the United Kingdom in the 1990s, the scope of this conduct-based immunity has been the subject of substantial international debate. ${ }^{2}$

Since 2007, the UN's International Law Commission has been considering the "Immunity of State Officials from Foreign Criminal Jurisdiction."3 In the summer of 2017, as part of its work on this topic, the Commission provisionally adopted Draft Article 7, which provides:

\section{Draft Article 7}

\section{Crimes under international law in respect of which immunity ratione materiae shall not apply}

1. Immunity ratione materiae from the exercise of foreign criminal jurisdiction shall not apply in respect of the following crimes under international law:

(a) crime of genocide;

(b) crimes against humanity;

(c) war crimes;

(d) crime of apartheid;

(e) torture;

(f) enforced disappearance.

2. For the purposes of the present draft article, the crimes under international law mentioned above are to be understood according to their definition in the treaties enumerated in the annex to the present draft articles. ${ }^{4}$

The adoption of this draft article was based on a recorded vote, with twenty-one members voting in favor, eight members voting against, and one member abstaining. ${ }^{5}$ In its Commentary on the draft article, the Commission

\footnotetext{
* William Van Alstyne Professor, Duke Law School.

1 See Arrest Warrant of 11 April 2000 (Dem. Rep. Congo v. Belg.), 2002 ICJ Rer. 3 (Feb. 14).

${ }^{2}$ For discussion of some of the relevant state practice since the Pinochet case, including national case law, see Jones v. U.K., 2014 EuR. CT. H.R. 176.

${ }^{3}$ For an earlier AJIL Unbound symposium relating to this International Law Commission project, see Symposium on the Immunity of State Officials, 109 AJIL Unbound (2015), with essays from William Dodge, Chimène Keitner, and Roger O’Keefe.

${ }^{4}$ See Int'l Law Comm'n, Report on the Work of Its Sixty-Ninth Session, UN Doc. A/72/10 (Sept. 11, 2017).

5 See id. at 164-65.
}

The American Society of International Law and Curtis A. Bradley (C) 2018. This is an Open Access article, distributed under the terms of the Creative Commons Attribution licence (http://creativecommons.org/licenses/by/4.0/), which permits unrestricted re-use, distribution, and reproduction in any medium, provided the original work is properly cited. 
cited various national laws and decisions in support of the proposition that "there has been a discernible trend towards limiting the applicability of immunity from jurisdiction ratione materiae in respect of certain types of behavior that constitute crimes under international law." 6

This Unbound symposium reflects on Draft Article 7 and also more broadly on the present and future state of foreign official immunity. The six essays in the symposium are authored by scholars from six different countries: China; France; the Netherlands; South Africa; the United States; and the United Kingdom. Five of the essays specifically discuss Draft Article 7, and the remaining essay considers the impact on foreign official immunity of referrals by the UN Security Council to the International Criminal Court.

Sean Murphy, a U.S. scholar who is also a member of the International Law Commission, argues that the Commission did not cite sufficient state practice to support a conclusion that the draft article is expressing existing law (lex lata). ${ }^{7} \mathrm{He}$ reviews the laws and cases cited by the Commission and finds that they do not support the nonapplication of immunity under existing customary international law for any of the six listed crimes. The state practice, in his view, "is not widespread, representative, or consistent." 8 Murphy concludes that Draft Article 7 "is not grounded in law, but in policy-making by the Commission." $\mathrm{He}$ also reports that it generated substantial disagreement when it was discussed in the UN General Assembly's Sixth Committee in October 2017.

Qinmin Shen, a scholar from China, similarly contends that the Commission cited insufficient state practice, and he reviews what the Commission cited in some detail. ${ }^{10}$ Among other things, he argues that much of the practice that was cited is not directly probative, because it concerns either state immunity rather than official immunity, immunity from international court jurisdiction rather than national court jurisdiction, treaty practice rather than practice under customary international law, or civil proceedings rather than criminal proceedings. He also contends that the Commission's selection of the particular crimes listed in Draft Article 7 was arbitrary and that its failure to list corruption shows that it was not applying its criteria consistently.

Philippa Webb, a scholar from the United Kingdom with particular expertise in immunity law, ${ }^{11}$ discusses some limitations associated with the International Law Commission's "systemic" approach to immunity, pursuant to which the current Special Rapporteur, in particular, treated state immunity, diplomatic immunity, and official immunity as interconnected and felt free to borrow or analogize from one area to another. ${ }^{12}$ While applauding the search for coherence, she notes that there are important differences in the ways that the various types of immunity have evolved. She concludes that "a single unifying concept of immunity is neither realistic nor desirable."13

Mathias Forteau, a French scholar and former member of the International Law Commission, highlights some potential shortcomings of Draft Article 7 while also considering some alternative approaches that the Commission could take. ${ }^{14}$ He discusses what he sees as several problems with the provisional adoption of the draft article: the failure to first consider procedural aspects of immunities; the difficulty of reconciling the draft article with 
the Commission's prior work on the obligation to extradite or prosecute; and the lack of consensus within the Commission on the relevant materials that would support the draft article. He argues that instead of trying to formulate a top-down approach to limitations on immunity, the Commission should "grant] a margin of appreciation to state authorities in charge of regulating immunities." 15 This could be done, for example, by recommending a new treaty-based rule or by offering guidance to domestic authorities about conditions under which they might choose not to grant immunity.

Rosanne van Alebeek, a scholar in the Netherlands who has written extensively about immunity, ${ }^{16}$ reviews the discussions in the International Law Commission in both 2011, when the Second Report of Special Rapporteur Kolodkin was discussed, and in 2016-2017, when the Fifth Report of Special Rapporteur Escobar and Draft Article 7 were discussed. Based on this review, she finds that there is now less consensus in support of treating an international crimes exception to official immunity as lex lata ${ }^{17}$ In particular, she reports that "where in 201157 percent of the members who participated in the debate expressed support for adopting some form of "international crimes' exception de lege lata," in 2017 that support had dwindled to 21 percent." 18 She attributes this shift in part "to the fact that the Special Rapporteur seemed to concede that the content of customary international law should first and foremost be derived from state practice, and that the principal arguments in favor of the 'international crimes' exception were only relevant outside that framework."19

Finally, Erika de Wet, a scholar from South Africa, considers a different issue relating to foreign official immunity: the relationship between immunity ratione personae and referrals for prosecution by the UN Security Council to the International Criminal Court (ICC). ${ }^{20}$ As has been widely discussed, this became an issue with respect to President Bashir of Sudan, after several countries declined to arrest him despite an arrest warrant issued by the ICC prosecutor. De Wet notes that in various decisions the ICC Pre-Trial Chamber has construed the 2005 Security Council referral of the situation in Sudan (in relation to Darfur) as effectively overriding the immunity of Sudan's head of state for purposes of cooperation with the ICC, under two different rationales: first, the Security Council resolution can be construed as imposing on Sudan an obligation to revoke the immunity of its head of state as part of its obligation under the resolution to cooperate with the ICC, or, second, the resolution can be construed as having the effect of extending the application of the Rome Statute in full to Sudan. De Wet finds "both lines of reasoning equally plausible" and notes that they appropriately reflect a purposive approach to interpreting Security Council resolutions. ${ }^{21}$

\footnotetext{
${ }^{15} I d$. at 25.

16 See, e.g., Rosanne van Alebeek, The Immunities of States and Their Officials in International Criminal Law (2008).

17 See Rosanne van Alebeek, The "International Crime" Exception to the ILC Draft Articles on the Immunity of State Officials from Foreign Criminal Jurisdiction: Two Steps Back?, 112 AJIL UnBound 27 (2018).

${ }^{18} I d$. at 30 .

${ }^{19} \mathrm{Id}$. at 27.

20 See Erika de Wet, Referrals to the International Criminal Court Under Chapter VII of the United Nations Charter and the Immunity of Foreign State Officials, 112 AJIL UnBOUND 33 (2018).

${ }^{21} I d$. at 36.
} 